\title{
BOUNDLESS OPPORTUNITIES WITH DEFINITE LIMITATIONS
}

\author{
Nikoletta KASZÁS ${ }^{\mathrm{a}}$, Erzsébet PETER ${ }^{\mathrm{b}}$, Krisztina KELLER ${ }^{\mathrm{b}}$, Tamás \\ KOVÁCS ${ }^{\mathrm{a}}$
}

\begin{abstract}
${ }^{a}$ University of Pannonia, Faculty of Business and Economics, Doctoral School of Management Sciences and Business Administration, 18. Zrínyi utca, Nagykanizsa, H-8800, phone: +36/30 473-50-11, +36 93 502 914, e-mail: kaszas.nikoletta@uni-pen.hu, kovacs.tamas@szabadics.hu

${ }^{\mathrm{b}}$ University of Pannonia, Nagykanizsa Campus, 18. Zrínyi utca, Nagykanizsa, H-8800, phone: +3693 502 914, e-mail: peter.erzsebet@uni-pen.hu, keller.krisztina@uni-pen.hu
\end{abstract}

Cite this article: Kaszás, N., Peter, E., Keller, K., Kovács, T. (2016). Boundless Opportunities with Definite Limitations. Deturope, 8, 1: 5-20

\begin{abstract}
In our comparative analyses we tried to identify those factors that can affect the success of the projects implemented at the border region. We involved three cross-border programs into our analyses and studied the project of the Austria-Hungary, Slovenia-Hungary and Hungary-Croatia Cross-border Co-operation Programmes. In this article we have undertaken to compare the results of these analyses and find out the similarities in the factors determining the project success. We assumed that there are no significant differences among the project success influencing factors in the studied programs, and the same or at least very similar affecting factors can determine the success. Our primary research proved this hypothesis, so thanks to it we can state that the projects implemented in the analysed cross-border cooperation programs are influenced by some organizational and individual factors: the time factor of the project success can be high if the project manager has direct management and monitoring rights and his or her authority does not depend on others; furthermore if the personality and the methodological competencies of the project manager are given. The project management success can be reached if the project manager has some managerial competencies, as well.
\end{abstract}

Keywords: project success, cross-border region, cross-border co-operation program

\section{INTRODUCTION}

\section{Cross-border cooperation in the frame of projects}

Since the 1990s the European Union has paid more and more attention to subsidising crossborder developments both in its own outer boundaries and in the border regions of future member states.

Cross-border cooperation programmes have been present in Europe since the 1990s and the European Committee has subsidised this form of cooperation with significant amounts:

- INTERREG I (1989-1993): 0.9 billion EUR

- INTERREG IIA (1994-1999): 2.9 billion EUR

- INTERREG IIIA (2000-2006): 4.9 billion EUR

- INTERREG IVC (2007-2013): 5.6 billion EUR (Lados, 2009) 
The INTERREG European Territorial Cooperation is one of the four Community Initiatives of the European Union. Its main aims are to promote cross-border, transnational and interregional cooperation, to facilitate economic and social cohesion, to ensure the balanced and sustainable development of Europe and to implement regional integration (http://www.szpi.hu, 13 July 2015). The cohesion is very needed, partly thanks to the enlargements in 2004 and 2007, when the development imbalance increased. Regarding the focus of our study it is more important that the differences in territorial development are even greater in the EU regions (Sarudi et al., 2011, p. 57).

We believe that the studied cross-border projects contributed to this approach: thanks to the partnership principle the organisations are forced to cooperate with institutions from other countries and they had to learn the different ways of collaboration and teamwork in order to manage success projects.

The European Union provided Hungary with subsidies for development prior to our accession in 2004 in order to achieve full member status as soon as possible. The first resources were partly financed by the above mentioned INTERREG III programmes and at the same time, another form of financing made its appearance, the PHARE programme.

The PHARE (Pologne, Hongrie Aide a la Reconstruction économique) programme was launched by the European Communities in 1989 with the purpose to provide support to strengthen political democracy, to train experts necessary for market transformation and to establish new institutions. However, more and more stress was put on financial and investment subsidies, environmental protection and privatisation in the coming years. From 1998 on the aim of the programme was to help the subsidised countries develop the conditions necessary for accession as a full member. From 2000 on the Phare programme focused on mainly the economic and social cohesion putting emphasis on building institutions with special regard to the related supporting investment and to 'twinning' programmes, which allowed Hungarian experts working together with their EU colleagues to improve the efficiency of their institutions.

Hungary signed financial agreements worth nearly 1.48 billion EUR with regard to PHARE subsidies between 1990 and 2003. Until 30 November 2005 (the last deadline of signing contracts) contracts for approximately 1.42 billion EUR were signed throughout the country. All this meant the realization of almost 200 sectoral and regional development programmes. The 'Phare-era' in Hungary came to end in 2006; that is, the programmes financed by the Phare pre-accession funds were finished. The programme facilitated Hungary to become a country fitting into the European Union regarding its economy and society and it 
prepared the country to be able to win even larger-scale funds (http://www.szpi.hu. 13 July 2015).

Mihály Lados (2009) summarized the most important differences between INTERREG and Phare programmes in one of his lectures, which are outlined in the following table (Tab. 1):

Table 1 Comparison of INTERREG and PHARE programmes

INTERREG

Objectives

Regions to be

supported

Programming

Financing

Decision making

Project selection

Project implementation

Project monitoring

Pre-financing

Source: Lados, 2009
Emphasis is on the new, external

EU borders

All border regions

Management-oriented documents, indicative planning for several years

Programme of several years

Decentralized on the level of the country or regions

The same selection criteria, common approval process, decision (proposal) by the Joint

Steering Committee

The goal: co-ordinated processes

Setting up a common reporting, monitoring system

Not characteristic
PHARE CBC

Emphasis on transformation and accession

Border regions neighbouring EU member states

Sector-oriented documents, separate programming practice, programming for several years/a single year

Indicative, annual financial decisions

Centralized (EC) based on the Financial Memoranda

Separate approval and decision making processes

Different financial regulations, different procurement regulations

Common reporting, monitoring and evaluating procedures

Characteristic

We can conclude that the EU has different aims with the two financial instruments. The INTERREG programs focus on the existing connections between countries and regions, so in our mind it is more suitable for solving common problems and improve the connections between institutions. However the PHARE programs focus on neighbouring EU member states and its main goal is the help of the accession. We believe that both programs have grounds and advantages. Two from the three studied programs are with the participation of two EU member states, while one was in an exceptional situation, due to Croatia accessed to the EU during the program period. 
In our study we focused on three different cross-border co-operation programs:

- Austria-Hungary Cross-Border Cooperation Program 2007-2013 (AT-HU)

○ priorities: Innovation, integration and competitiveness; Sustainable development and accessibility;

- Slovenia-Hungary Cross-Border Cooperation Program 2007-2013 (SI-HU)

○ priorities: Sustainable environment and Tourism; Co-operative Economy and human resource development among communities;

- Hungary-Croatia IPA Cross-Border Cooperation Program 2007-2013 (HU-HR)

○ priorities: Increasing the attractiveness of cooperation area; Co-operative Economy and human resource development among communities.

Common feature of the programs are that the supported projects receive funding from the EU up to a maximum of $85 \%$ of their total costs while $10 \%$ national public co-financing and $5 \%$ own resources have to be ensured. In the most program public or public equivalent bodies, non-profit organisations and other institutions that act in the public interest can act as lead partners or partners in the projects. In accordance with the above the following legal entities could be: national, regional or local authorities, municipalities, universities, bodies mainly financed or governed by public institutions, non-profit organisations and associations.

The organisations above could submit their application in the frame of a consortium, where the project partnership must consist of at least one organisation from each country. The Lead Partner organisation coordinated the project development and submitted the completed application; it is also responsible for the implementation of the joint project and the project management.

During the 2007-2013 periods:

- a total of 87 projects received funding in the AT-HU Programme, which meant 358 project partners;

- a total of 41 projects received funding in the SI-HU Programme, which meant 190 project partners;

- a total of 154 projects received funding in the HU-HR Programme, which meant 466 project partners (Palyazat.gov, 2014).

We can see that the most projects were supported in the HU-HR program. It is not surprising, as at the start of the program (in 2007) Croatia was not the member of the EU, so the cooperation between Croatia and Hungary was supported by a special fund, the IPA (Instrument for Pre-Accession Assistance). The IPA supports the cooperation of such 
countries, where one of the partners is situated outside the EU borders and has accession talks or can access to the EU in the medium term.

We also know, that in the SI-HU programs the project partnership consist of much more partners (5-8) than in the case of the AT-HU programs (2-4), this can be the reason that twice as much project was supported in the AT-HU program then in the SI-HU.

\section{Cultural differences in the border region}

In order to analyse the national culture we have taken Hofstede's culture model as a starting point and have compared the results of the studied countries based on the six dimensions.

Based on Fig. 1 it can be concluded that in the dimension of power distance there is a remarkable differences between countries. "Power Distance is defined as the extent to which the less powerful members of institutions and organisations within a country expect and accept that power is distributed unequally." While this dimension is clearly low in Austria that is independence, equal rights, the accessibility of a superior and empowerment mean true values in this culture; Hungary has a medium value in this dimension. These values are only partly present in the Hungarian culture. In the case of Slovenia and Croatia people accept a hierarchical order in which everybody has a place and which needs no further justification. As we see it, the lower power distance experienced in the Austrian side of the border can be beneficial regarding projects since the presence and the support of a senior executive are given high importance when it comes to the success of projects. Furthermore, in order to gain support it is essential that the project manager can directly reach a senior executive.

Figure 1 Culture dimensions of the examined countries according to the Hofstede model

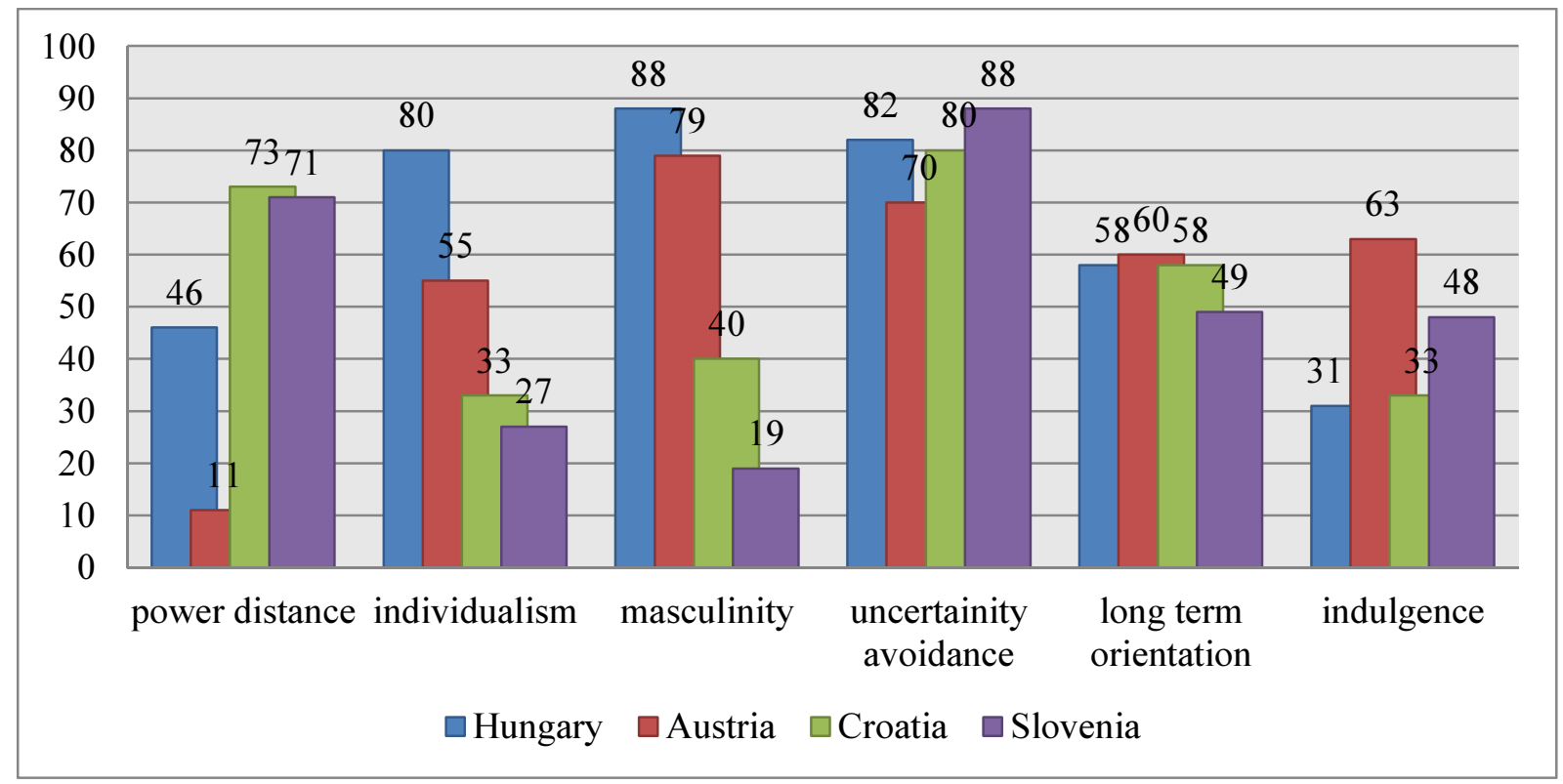

Source: http://geert-hofstede.com (estimated values) 
With regard to individualism-collectivism it can be seen that Hungary is much more "selfcentred' than the other countries. "In Individualist societies people are supposed to look after themselves and their direct family only. In Collectivist societies people belong to 'in groups' that take care of them in exchange for loyalty." All these can be vital in case of applications based on partnerships since team work and collaboration are essential to implement projects successfully. Therefore, it can be concluded that Hungary is at a disadvantage in this respect compared to its neighbour.

When emphasizing masculinity vs. femininity there is a smaller difference observed between Hungary and Austria, but bigger one between Hungary and Slovenia. "A high score (Masculine) on this dimension indicates that the society will be driven by competition, achievement and success, with success being defined by the winner / best in field - a value system that starts in school and continues throughout organisational life. In Masculine countries people "live in order to work", managers are expected to be decisive and assertive, the emphasis is on equity, competition and performance and conflicts are resolved by fighting them out." On the other hand Croatia and especially Slovenia seems more feminine countries, that means the dominant values in society are caring and the quality of life. In this kind of society the quality of life is the sign of success and standing out from the crowd is not admirable.

With respect to uncertainty avoidance, it seems that both countries would rather avoid than look for risks, which is not favourable to developing projects that bear the characteristics of being uncertain. The relevance of which can be easily realised if we analyse Hofstede's description of uncertainty avoidance behaviour: "Countries exhibiting high Uncertainty Avoidance maintain rigid codes of belief and behaviour and are intolerant of unorthodox behaviour and ideas. In these cultures there is an emotional need for rules (even if the rules never seem to work) time is money, people have an inner urge to be busy and work hard, precision and punctuality are the norm, innovation may be resisted, security is an important element in individual motivation."

Regarding long term orientation, no significant difference can be experienced between the countries; all are slightly drawn to being pragmatic; however, they still represent medium values. "In societies with a pragmatic orientation, people believe that truth depends very much on situation, context and time. They show an ability to adapt traditions easily to changed conditions, a strong propensity to save and invest, thriftiness and perseverance in achieving results."

Finally, looking into the dimension of indulgence it can be observed that Hungary and Croatia in this respect are rather cynical and pessimistic while Austria and partly Slovenia are 
drawn to being indulgent. "Restrained societies do not put much emphasis on leisure time and control the gratification of their desires. People with this orientation have the perception that their actions are restrained by social norms and feel that indulging themselves is somewhat wrong."

Ákos Jarjabka has argued in his research on the national-organisational culture of Centraland Eastern-European countries that according to Hofstede's model Austria can be listed as a 'well-oiled machine', therefore, strong planning and controlled processes are characteristics. According to the author, Hungary can also be classified into this category so there is no difference between the two countries in this respect. The two other examined countries, Croatia and Slovenia belong to the "pyramid" group, which is characterized by the autocratic leadership and bureaucracy (Jarjabka, 2010).

As we can see in the above chapter, from some aspects (individualism, masculinity) there are significant differences in the culture of the studied countries. Nevertheless we assumed that the border-effect and the strong cultural and economic connections in the border region can decrease and smooth these differences.

\section{OBJECTIVES AND METHODS}

Molnárné Barna et al. declared that the EU funds do not necessarily support the most disadvantaged regions, but more the "good" projects (Molnárné Barna et al., 2010, p. 124). Based on this statement in the course of our research we studied the success of projects in the frame of the Austria-Hungary, Slovenia-Hungary and Hungary-Croatia Cross-Border Cooperation Programmes. Furthermore, our aim was to explore those organisational and individual factors that can influence the above mentioned project success. According to our initial hypothesis we assumed that there are no significant differences among the project success influencing factors in the studied programs, and the same or at least very similar affecting factors can determine the success.

During the research we explored and analysed the correlation between the certain factors relying on quantitative data. Based on the related chapters of scientific literature and the findings of previous researches the research model was developed, which presents the potential relations between the analysed elements.

According to the initial model of our research we wish to identify the success criterion of cross-border projects. Relying on the theories studying project success and on the models we analyse the success of cross-border projects through factors to be judged both objectively and subjectively (Fig. 2). 
Figure 2 Research model

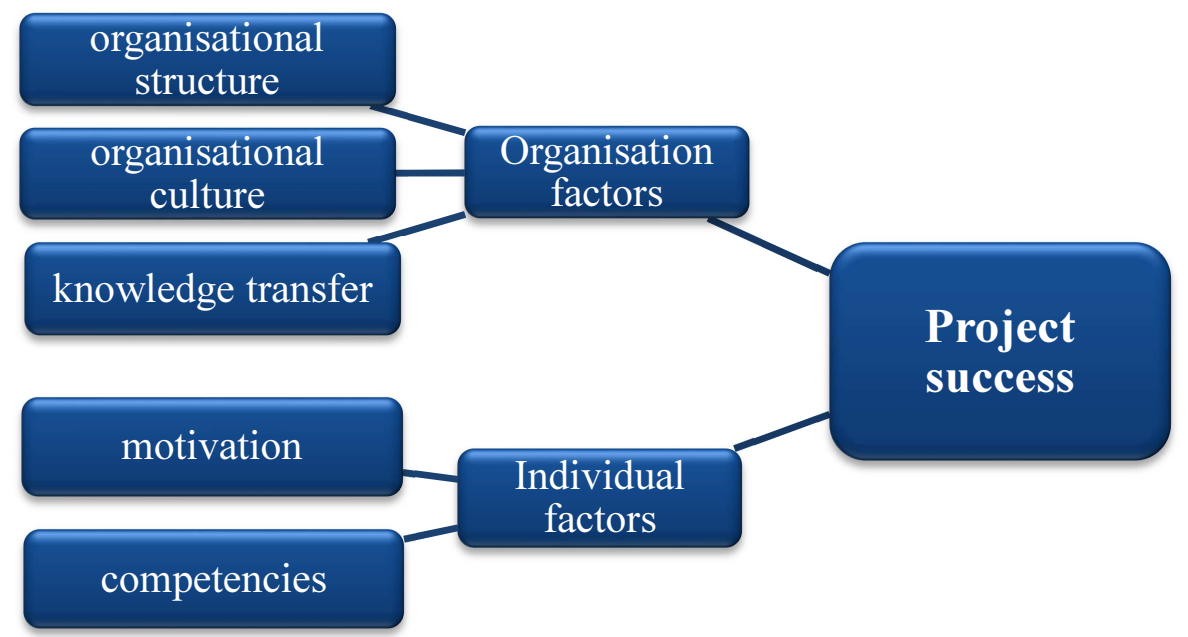

Having studied the scientific literature we assumed that these dimensions of success can primarily be influenced by various organisational and individual factors; therefore, we conduct our research of the correlation between these variables based on the empirical data. According to the 'explanatory' side of the research model we shall explore the organisational factors of cross-border projects through analysing three areas: through organisation structure, organisational culture and through organisation development of competencies and knowledge transfer. With regard to individual factors we examine the motivation and competencies of project coordinators.

In our research we made up our questionnaire based on comprehensive secondary analyses. The empirical research was based on questioning the organisations implementing cross-border projects in the analysed programs between 2007 and 2013 and the received data was examined through statistical and econometrics analyses. Since the empirical research concerned several countries; thus, the questionnaire was not only developed in Hungarian but also in German, Slovenian and Croatian languages, as well. The questionnaires were sent electronically via e-mails to the partner organisations in the studied programme.

\section{Characteristic features of the sample}

The geographical area of the questionnaire survey was limited by the geographical boundaries of the studied programmes according to what is laid down in the program documents:

- Hungary: Baranya, Somogy, Zala, Vas and Győr-Moson-Sopron counties

- Austria: Wien, Wiener Umland-Südteil, Nord-, Mittel- and Südburgenland counties

- Slovenia: Pomurska and Podravska regions 
- Croatia: Međimurska, Varaždinska, Koprivničko-križevačka, Bjelovarsko-bilogorska, plus Virovitičko-podravska, Požeško-slavonska, Osječko-baranjska and Vukovarskosrijemska counties as associated regions.

In the course of our research we aimed for questioning the entire population and sent our questionnaire to every organisation implementing projects that could be contacted online. Data collection through questionnaires lasted from May 2014 to late July in case of SloveniaHungary and Hungary-Croatia programs, while the data collection lasted from July 2015 to late August in case of Austria-Hungary program. We sent a total of 924 e-mails to the four countries and it involved 432 Hungarian, 143 Austrian, 238 Croatian and 111 Slovenian project managers. 292 responses out of the 924 questionnaires arrived that could be evaluated; the distribution is presented in Tab. 2.

Table 2 Population and sample from the four studied countries

$\begin{array}{lccc} & \text { population } & \text { sample } & \text { response rate } \\ \text { Hungary } & 432 & 146 & 33,8 \% \\ \text { Austria } & 143 & 38 & 26,6 \% \\ \text { Slovenia } & 111 & 35 & 31,5 \% \\ \text { Croatia } & 238 & 73 & 30,7 \% \\ \text { total } & 924 & 292 & 31,6 \%\end{array}$

Regarding the research methods we carried out factor analysis (maximum likelihood method) in order to test the relevance of the assumed variables given by the scientific literature and also chosen by ourselves in the surveyed area. On the basis of the created variables defined by the factor analysis, by means of cluster analysis we formed groups of the surveyed organizations. Finally we used the correlation analyses in order to find out the connections among the factors.

\section{RESULTS}

In the past year we analysed the projects in the Hungary-Croatia IPA (HU-HR) and the Slovenia-Hungary (SI-HU) Cross-border Cooperation Programmes implemented between 2007 and 2013. The next stage of this comprehensive research was the analysis of the projects implemented between Austria and Hungary and the scope of factors determining success.

First of all we used factor analyses in order to determine the success criteria of the project success in the cross-border regions. Regarding the success criteria of projects implemented in the HU-HR and SI-HU programmes we involved 16 variables into the analyses. The analyses 
proved three success criteria with $0,841 \mathrm{KMO}$ value, which compressed 9 variables from the original 16. The total variance ratio, as the index of the explanatory capacity of the factors analyses was $62,188 \%$, which also support the success of analyses. Regarding the success criteria of projects implemented in the AT-HU programme we involved the same 16 variables into the analyses, which proved the existence of three success criteria with 0,666 KMO value. The three factors compressed 8 original variables. The total variance ratio, was $57.083 \%$ in this case which also support the success of analyses.

According to the preceding and also to present research results we defined project success with 3-3 major factors, which are fairly harmonising in the 3 programs, as it can be seen in table 3 .

In relation to the time factor activities turn up in the same way as the closing of the project in time. With respect to project management success, the complete implementation of activities and indicators are present in each studied programme with the completion of the project contribution to the goals of the cooperating organisation in the case of AT-HU projects. Finally, the content of the variables defined by the factor relating to the target group is in a complete agreement.

Table 3 Comparison of success criteria of implemented projects in the HU-HR, the SI-HU and the AT-HU programmes

Success criteria of projects implemented in the HU-HR and SI-HU programmes

- implementation of activities meet deadline

Time factor

- closing of the project happens on schedule

- meeting reporting and correction deadlines

- project outputs realised

- project indicators achieved

Project management success

- project performed activities

Project management success

- the project reached its target groups

Satisfaction of target group

- satisfaction of target groups

Target group factor

- members of the target group participated in project events
Success criteria of projects implemented in the AT-HU programme

- implementation of activities meet deadline

- closing of the project happens on schedule

- project indicators achieved

- project activities performed

- project contribution to the goals of the contributing organisation

- the project reached its target groups

- satisfaction of target groups

- members of the target group participated in project events 
During the analyses based on the above factors we classified the studied organisations into clusters with the help of K-means cluster method. With regard to the Croatian-Hungarian and the Slovenian-Hungarian programmes the existence of four, statistically justified clusters were confirmed just as well as in relation with the Austrian-Hungarian programme.

Table 4 Final cluster centers of the organizational clusters in the Croatian-Hungarian and the Slovenian-Hungarian programmes

\begin{tabular}{lcccc} 
Factors & \multicolumn{4}{c}{ Final cluster centers } \\
& 1 & 2 & 3 & 4 \\
Time factor &, 15694 & $-1,67236$ &,- 12194 &, 37640 \\
Project management success &, 39442 &, 23358 & $-1,73132$ &, 29400 \\
Satisfaction of target group & $-1,11078$ &, 38296 &,- 29201 &, 64670
\end{tabular}

Table 5 Final cluster centers of the organizational clusters in the Austrian-Hungarian programme

\begin{tabular}{lcccc} 
Factors & \multicolumn{4}{c}{ Final cluster centers } \\
& 1 & 2 & 3 & 4 \\
Time factor & $-1,29344$ &, 11222 &, 69882 &, 15153 \\
Project management success &, 15985 & $-2,10435$ &, 29423 &, 30934 \\
Target group factor &,- 39398 &,- 15476 &,- 79788 &, 74113
\end{tabular}

Although there appears to be overlapping in the 4-4 clusters there are significant differences. In both analyses such organisations can be found that focus on the organisation's internal satisfaction; namely on the project management success and there are some that can be considered successful among the studied organisations. In the HU-HR and the SI-HU programmes a set could be clearly identified that struggled with time-related problems, whereas it was not that relevant in the AT-HU programme. In this latter case the applicants had difficulties with project management tasks. 
Figure 3 Comparison of success clusters of implemented projects in the HU-HR, the SI-HU and the AT-HU programmes

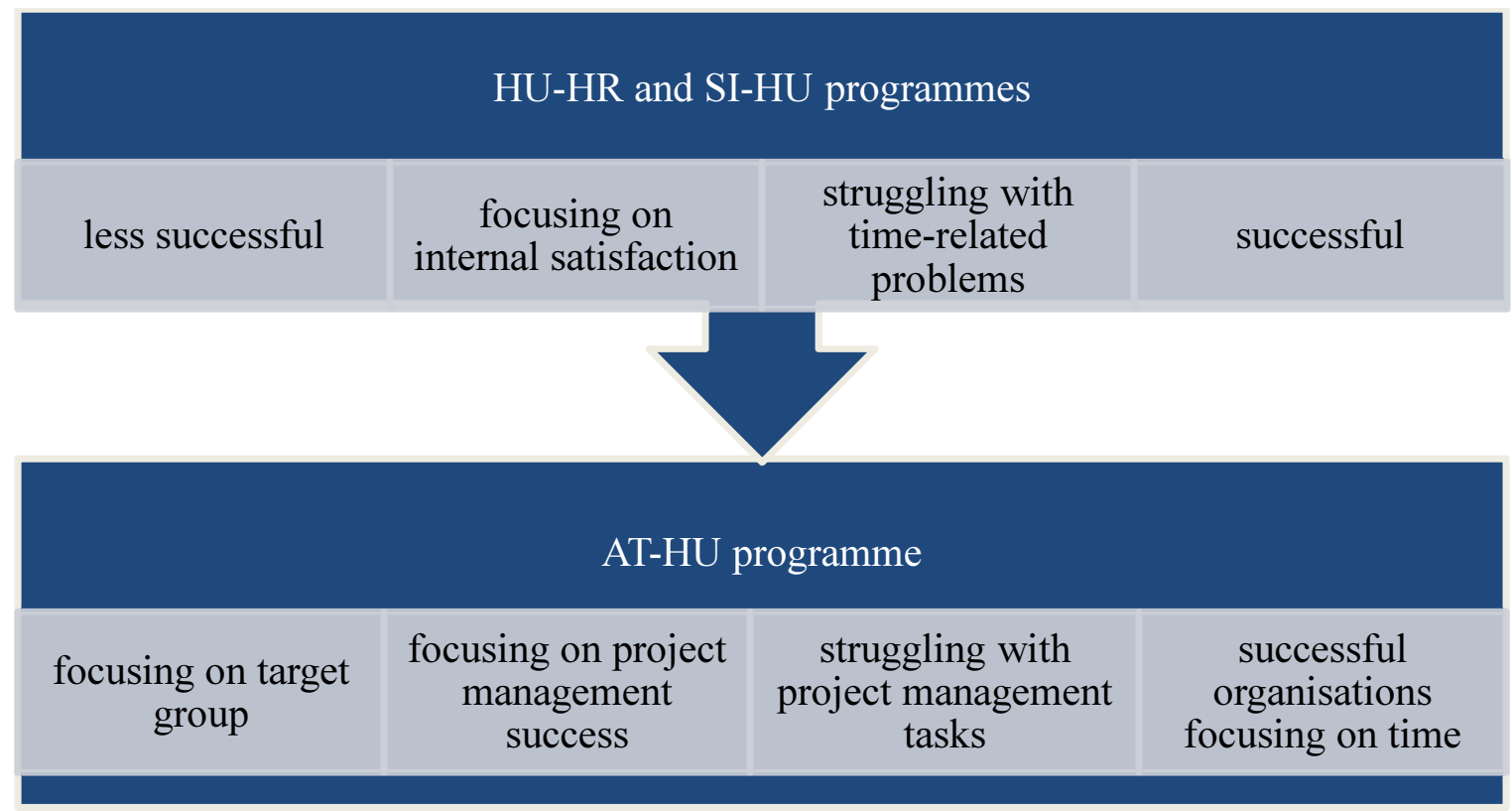

In the scope of both the previous (HU-HR and SI-HU programs) and the present (AT-HU program) research we carried out a correlation analysis, which explored those organisational and human factors that could influence the success criteria of projects.

With respect to Hungary-Croatia-Slovenia this analysis brought in the results presented in the following figure.

The regression analyses proved that:

- the two influencing factors explain $2,4 \%$ of the success in time factor: the standardized coefficient (Beta) of the Place and role of project manager in corporate structure factors was -0.128 ; the standardized coefficient (Beta) of the Competence arising from personality factors was 0,117

- the influencing factor explain $4,2 \%$ of the project management success factor: the standardized coefficient (Beta) of the Competence arising from personality factors was $-0,190$

- the influencing factor explain $3,8 \%$ of the success the satisfaction of target group factor: the standardized coefficient (Beta) of the Competences regarded important factors was $-0,207$. 
Figure 4 The findings of regression analysis in the HU-HR and the SI-HU programmes with regard to project success
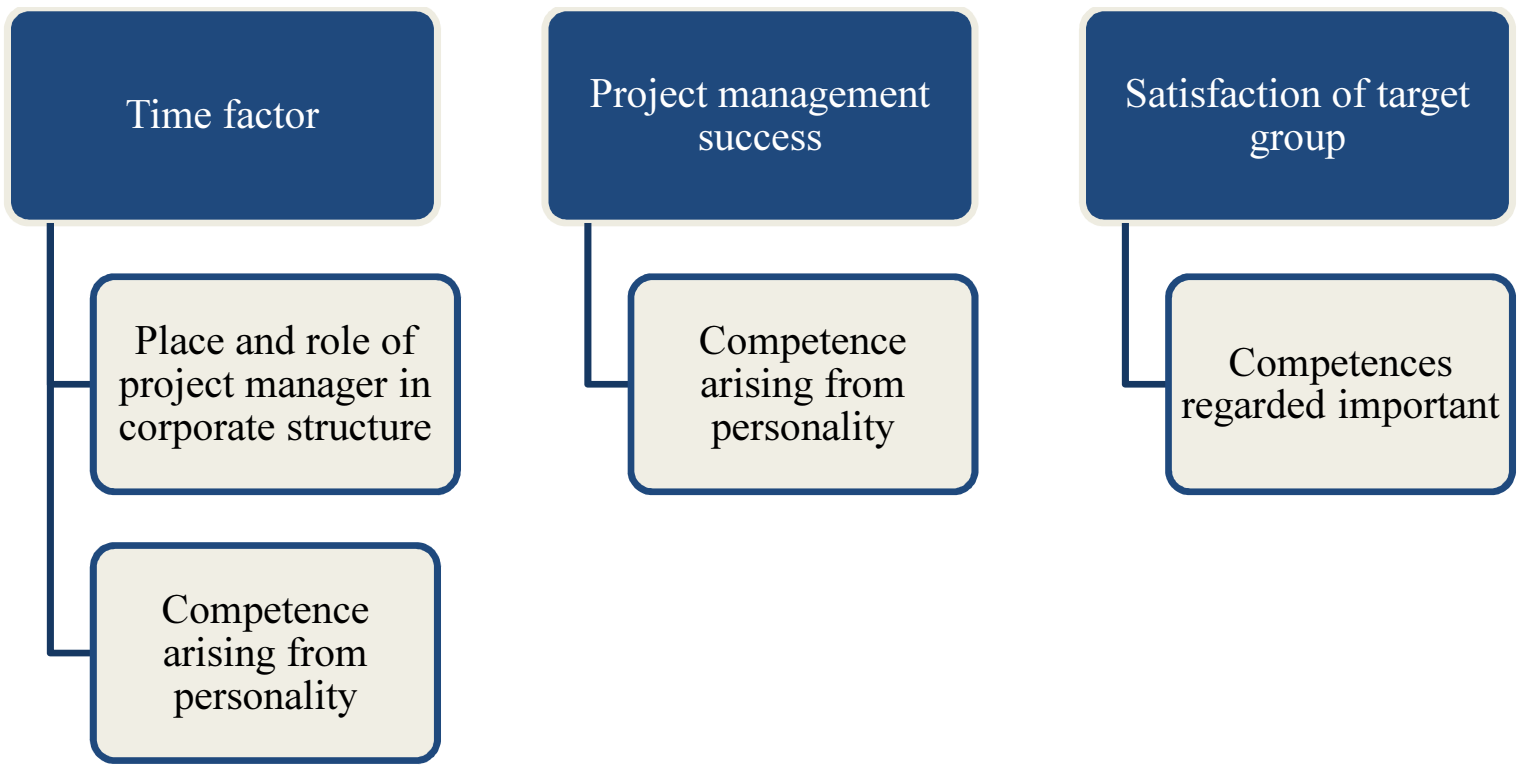

This analysis brought about slightly different results in the Austria-Hungary Cross-border Cooperation (Fig. 5).

The regression analyses proved that:

- the four influencing factors explain $5,1 \%$ of the success in time factor: the standardized coefficient (Beta) of the Place and role of project manager in corporate structure factors was $-0,381$; the standardized coefficient (Beta) of the Characteristics of market culture factors was 0,282; the standardized coefficient (Beta) of the External motivation factors was 0,209; the standardized coefficient (Beta) of the Social and methodological competences factors was 0,220

- the influencing factor explain $2,6 \%$ of the project management success factor: the standardized coefficient (Beta) of the Typical managerial competences factors was $-0,196$

- the influencing factor explain $9,4 \%$ of the success the satisfaction of target group factor: the standardized coefficient (Beta) of the Typical managerial competences factors was $-0,325$. 
Figure 5 The findings of regression analysis in the AT-HU programmes with regard to project success
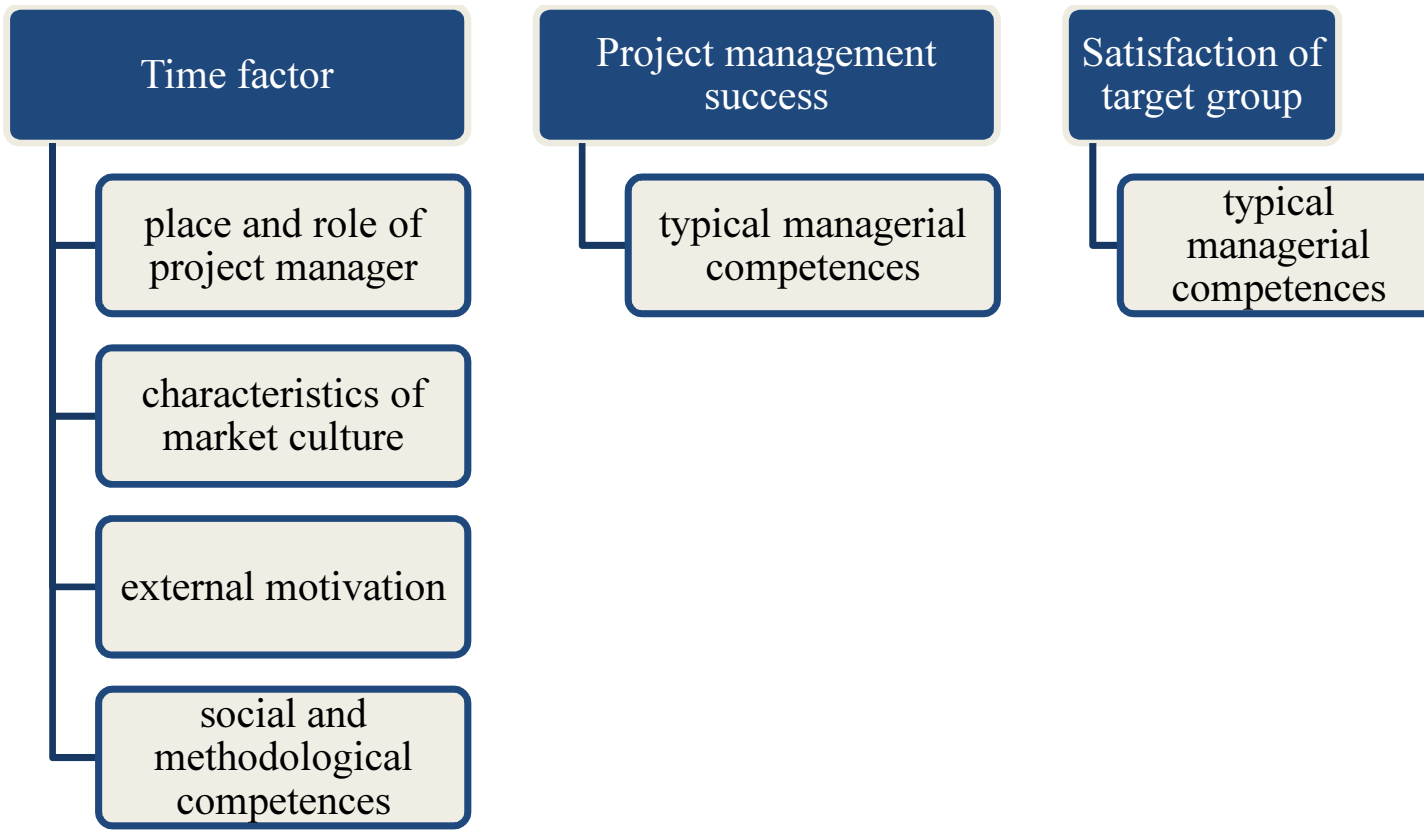

It is evident that the organisational structure, precisely the place and role of the project manager is definitely an important influencing factor with regard to time. It can also be seen that competences arising from personality, that is social and methodological competences appear in case of all three studied programmes. However, a new influential factor is the external motivation of the project manager.

Regarding the success of the organisation or of the project management tasks in our previous studies we determined personality traits as influencing elements, while in the instance of the AT-HU programme the managerial competences, which are of similar content, have the same role.

Finally, concerning the satisfaction of the target group last year's analyses confirmed the scope of competences regarded important by project managers as of significant influence; whereas in the present research it has been found that the managerial competences are also the ones that have an impact on the satisfaction of the target group.

\section{CONCLUSION}

All in all it can be concluded that the research results of the projects implemented with the participation of Austria-Hungary between 2007 and 2013 are in remarkable accordance with the findings of the previous stages of the research. 
First of all we can conclude that the success criteria of implemented projects in the programs are very similar. We could define the same three factors: time factor, project management success, satisfaction of target group. There are slight differences in the content of the factors. However it is interesting, that even though we could group the studied organisations into 4-4 groups in each survey, there are differences in the cluster characteristics and accordingly in the names of it, as it was explained in the our study.

We assumed that there are no significant differences among the project success influencing factors in the studied programs, and the same or at least very similar affecting factors can determine the success. Our primary research proved this hypothesis, so thanks to it we can state that the projects implemented in the analysed cross-border cooperation programs are influenced by some organizational and individual factors; so the project success is affected by the role and place of the project manager in the organisational structure and the competences of the project manager.

Regarding the cross-border projects we can accept the following general statements. The time factor of the project success can be high if the project manager has direct management and monitoring rights and his or her authority does not depend on others; furthermore if the personality and the methodological competencies of the project manager are given. The project management success can be reached if the project managers have some managerial competencies, as well.

\section{Acknowledgment}

This research was realised in the framework of the TÁMOP 4.2.1.D-15/1/KONV-2015-0006 - The development of the innovation research base and knowledge centre in Köszeg in the frame of the educational and research network at the University of Pannonia key project,which is subsidised by the European Union and Hungary and co-financed by the European Social Fund.

Erzsébet Péter's research was supported by the European Union and the State of Hungary, co-financed by the European Social Fund in the framework of TÁMOP 4.2.4. A/2-11-1-2012-0001 'National Excellence Program'. -,Hungarian National Excellence Programme for students and researchers in the convergence region".

\section{REFERENCES}

Hofstede, G. (2014). The Hofstede Centre, http://geert-hofstede.com/hungary.html (2015. július 14.)

Jarjabka, Á. (2010). Hasonlóságok és különbségek a közép- kelet európai országok nemzetiszervezeti kultúrájában. Merre tovább? Gazdaság és társadalom, realitás és esély, 10. Tudományos konferenciasorozat a Magyar Tudomány Ünnepe 2010 tiszteletére, 2010.11.4-5. Budapest. Programfüzet abstract, pp. 76 (Jarjabka, Á. (2010): Similarities and differences in the national-organisational culture of Central-Eastern European countries. Where to go further? Economy and society, reality and prospects, 10th 
scientific conference series in honour of the Festival of Hungarian Science, 2010.11.4-5. Budapest. Program me booklet, abstract, pp. 76)

Kaszás, N., Péter, E. (2014). A határon átnyúló projekteket lebonyolító szervezetek jellemzői, sikeressége. XVIII. Apáczai-napok Nemzetközi Tudományos Konferencia. Győr, 2014. október 21-22.

Lados, M. (2009). A PHARE CBC és INTERREG-től az Európai Területi Együttmüködési Programokig. MRTT Vándorgyülés Szabadka, 2009. november 13. (Lados, M. (2009): From PHARE CBC and INTERREG to European Regional Cooperation programmes. MRTT Congress Szabadka, 13 November 2009) To be downloaded: http://www.google.hu/url?sa $=$ t\&rct=j\&q=\&esrc $=$ s\&source $=$ web $\& \mathrm{~cd}=3 \& \mathrm{cad}=\mathrm{rja} \& u a c t=$ $8 \&$ ved $=0 \mathrm{CDAQFj} A C \& u r l=\mathrm{http} \% 3 \mathrm{~A} \% 2 \mathrm{~F} \% 2 \mathrm{Fwww} . \mathrm{mrtt} . \mathrm{hu} \% 2 \mathrm{Fvandorgyulesek} \% 2 \mathrm{~F} 20$ 09\%2F1\%2Flados.ppt\&ei=PKWjVe3bF4m1sQHYw7jIBw\&usg=AFQjCNE1 soTbq0d AFCyim98CDCjDI20fVA\&sig2=efjjybeL4QHB_6jqxVNJYQ\&bvm=bv.97653015,d.b Gg. 13 July 2015

Molnárné Barna, K., Molnár, T., Balázs, F. (2010). Dél-Dunántúli Régió Pályázati Tevékenysége. Deturope - The Central European Journal Of Regional Development and Tourism. Vol. 2 Issue 2. ISSN 1821-2506. p. 124.

Pályázat.gov (2014). ETE, IPA, ENPI 2007-2013, http://palyazat.gov.hu/europai_teruleti_egyuttmukodes_ipa_enpi_2007_2013. Date of downloading: 15 July 2014

Sarudi, Cs., Molnárné Barna, K., Horváthné Kovács, B. (2011): Regional differences in the European Union. Deturope - The Central European Journal Of Regional Development and Tourism. Vol. 3, No. 1. ISSN 1821-2506

Széchenyi Programiroda (2015). Európai Uniós Fejlesztési Programok (Széchenyi Programme office, 2015: European Union Development Programmes. To be downloaded:

http://www.szpi.hu/index.php?action=recordView\&type=places\&category_id=3868\&id $=966513.13$ July 2015 